Jurnal Geocelebes Vol. 1 No. 2, Oktober 2017, 43 - 52

\title{
PERUBAHAN PENGGUNAAN LAHAN DI KECAMATAN SIRIMAU KOTA AMBON
}

\author{
Beatus M. Laka, Uca Sideng, Amal \\ Program Pascasarjana Pendidikan Geografi Universitas Negeri Makassar \\ Penulis koresponden. Alamat email: lakamendelson@gmail.com
}

\begin{abstract}
Abstrak
Penelitian ini bertujuan untuk mengetahui luasan masing-masing perubahan penggunaan lahan Kecamatan Sirimau dilihat dari citra satelit tahun 2006-2016, mengetahui agihan perubahan penggunaan lahan Kecamatan Sirimau dilihat dari citra satelit tahun 2006-2016, dan untuk mengetahui faktor-faktor apa saja yang mempengaruhi terjadinya perubahan penggunaan lahan di Kecamatan Sirimau.

Penelitian dilaksanakan pada bulan Maret-April 2016 di Kecamatan Sirimau Kota Ambon. Penelitian ini adalah penelitian survey karena sebagian besar data secara langsung diolah dengan menggunakan metode pengamatan dan pengukuran lapangan. Subjek penelitian ini adalah perubahan penggunaan lahan di Kecamatan Sirimau Kota Ambon. Pengambilan data dalam penelitian ini adalah menggunakan sistem informasi geografi (SIG). Teknik analisis data yang digunakan adalah analisis menggunakan SIG dan deskriptif, data yang diperoleh dari hasil analisis SIG di sajikan dalam bentuk peta overlay yaitu peta penggunaan lahan tahun 2006-2016 Kecamatan Sirimau Kota Ambon. Peta ini kemudian ditumpang tindih, kemudian menghasilkan peta baru dan tabel perubahan penggunaan lahan kemudian dijelaskan secara deskriptif. Selanjutnya data yang diperoleh dianalisis kembali dengan menggunakan teknik analisis spasial keruangan untuk memaparkan perubahan penggunaan lahan yang terjadi di Kecamatan Sirimau dalam kurun waktu sepuluh tahun dengan menggunakan software arcgis versi 10.3. Setelah itu data yang berupa peta perubahan penggunaan lahan tahun 2006 dan 2016 dianalisis untuk mengetahui berapa besar agihan perubahannya.

Berdasarkan hasil penelitian dapat disimpulkan bahwa perubahan luasan penggunaan lahan Kecamatan Sirimau Kota Ambon 10 tahun terakhir sangat besar untuk permukiman sebesar 1036,1 Ha dari tahun sebelumnya sebesar 966,9 Ha. Agihan perubahan penggunaan lahan Kecamatan Sirimau Kota Ambon 10 tahun terakhir mengarah ke selatan dan timur yaitu ke daerah pesisir pantai dan pegunungan, adapun perubahan penggunaan lahan kea rah timur di dominasi oleh perubahan dari lahan hutan dan lahan pertanian kering berubah ke lahan permukiman. Faktor-faktor yang mempengaruhi perubahan penggunaan lahan adalah tingginya tingkat laju pertumbuhan penduduk Kecamatan Sirimau yaitu sebesar 5,54\% dengan kepadatan penduduk kurang lebih $1.925 \mathrm{orang} / \mathrm{Km}^{2}$.
\end{abstract}

Kata kunci: perubahan penggunaan lahan, Sirimau

\section{Abstract}

This study aimed to find out the extent of each transformation of the land use at Sirimau Subdistrict seen from the satellite images in 2006-2016, to find the land use transformation at Sirimau Sub-district seen from satellite images in 2006-2016, and to find out what factors affect the occurrence land use transformation at Sirimau Sub-district. 
The research was conducted in March-April 2016 at Sirimau Sub-district, Ambon City. This research is survey research because most of the data directly processed by using the observation method and the field measurement. The subject of this research is the land use transformation at Sirimau Sub-district, Ambon City. The data collection in this research is using geographic information system (GIS). The technique of data analysis used is analysis using GIS and descriptive, the data obtained from the result of GIS analysis presented in the form of overlay map that is the land use map of the year 2006-2016 Sirimau Sub-district, Ambon City. This map is then overlapped, then generates the new maps and tables of land use transformation then described descriptively. Furthermore, the data obtained were re-analyzed by using the spatial analysis techniques to describe the transformation of land use that occurred in Sirimau Sub-district within a period of ten years using Arcgis software version 10.3. After that, the data in the form of the land use transformation maps in 2006 and 2016 were analyzed to find out how big the change was.

Based on the results of the research can be concluded that the change of land area of Sirimau Sub-district of Ambon City at the last 10 years is very big for settlements of $1036.1 \mathrm{Ha}$ from the previous year amounted to 966.9 Ha. The direction of the land use transformation at Sirimau Subdistrict of Ambon City for the last 10 years has led to the south and the east to the coastal and mountainous areas, while the transformation of land use to the east is dominated by the transformation from the forest land and the dry farm land to settlements. The factors that influence the land use transformation are the high rates of the population growth of Sirimau Sub-district which is 5.54\% with the population density of approximately 1,925 people $/ \mathrm{Km}^{2}$.

Keywords: land use transformation, Sirimau

\section{Pendahuluan}

Perubahan penggunaan lahan merupakan suatu proses perubahan dari penggunaan lahan sebelumnya ke penggunaan lahan lain yang bersifat permanen maupun sementara dan merupakan konsekuensi dari adanya pertumbuhan dan transformasi perubahan struktur sosial ekonomi masyarakat yang sedang berkembang baik untuk tujuan komersial maupun industri (Muiz A. 2009). Perubahan penggunaan lahan terjadi karena adanya keperluan untuk memenuhi kebutuhan penduduk untuk yang terus meningkat.

Sejalan dengan itu Siahaan, 1987 dalam Suhendy, 2009 mengataan bahwa, peningkatan kualitas dan kualitas hidup itu akhirnya akan berdampak pada perubahan penggunaan lahan yang menjadi sulit dikendalikan sehingga menyebabkan kondisi sumberdaya alam terganggu, aliran airpermukaan menjadi cepat dan lebih banyak sumur-sumur menjadi kering. Dengan adanya peningkatan jumlah penduduk dapat menyebabkan semakin meningkatnya pembangunan, khususnya pembangunan di bidang permukiman.
Pembangunan tersebut tentunya membutuhkan alokasi lahan tersendiri dan jika tidak terpenuhi akibat keterbatasan lahan dengan peningkatan jumlah penduduk.

Ditinjau dari ilmu geogrfi, maka yang menjadi titik berat dari tanah dan lahan adalah melihat tanah dan lahan sebagai suatu lokasi atau tempat sebagai suatu ruang yang didalamnya terjadi interasksi antara komponen fisis dan komponen sosial dimana keduanya saling berpengaruh. Artinya segenap unsur yang terdapat dalam ruang merupakan suatu sistem saling terkait (Ismail, 1999).

Badan Pertanahan Nasional BPN, 1997 dalam Suhendy, 2009 menyatakan bahwa dari hasil evaluasi terhadap penggunaan lahan yang ada di kota Ambon selama tahun 1980-1995, pergeseran penggunaan lahan yang terjadi cukup signifikan, dimana untuk pemukiman terjadi sebesar $+16,45 \%$, tegalan $-2,43 \%$, perkebunan $0,21 \%$ kebun campran $-7,30 \%$, hutan $0,12 \%$ dan alang-alang-6,59\%.Itu berarti bahwa perubahan penggunaan lahan yang ada, adalah terjadinya konversi lahan dari 
kawasan bervegetasi menjadi kawasan terbangun. Ini semuadiakibatkan karena laju pertumbuhan penduduk yang meningkat sejalan dengan perubahan waktu akibat dari peningkatan penduduk maka dapat menyebabkan perubahan alih fungsi lahan.

Kenyataan tersebut diatas terus terjadi sepanjang sejarah kehidupan manusia tak terkecuali di Indonesia. Indonesia yang termasuk dalam Negara dengan jumlah dan pertumbuhan penduduk yang sangat besar dan berpenduduk banyak terus mengalami perubahan penggunaan lahan setiap tahunnya. Diperkirakan jumlah penduduk di Indonesia pada tahun 2016 adalah 273 juta jiwadengan persentase pertumbuhan penduduk 1,49 persen pertahun. Jumlah penduduk di setiap wilayah/propinsi dan kabupaten maupun pulau juga berbeda-beda, demikian juga dengan angka pertumbuhan penduduknya berbeda pula. Seperti di Kota Ambon Provinsi Maluku yang mengalami pertumbuhan penduduk sangat pesat setiap tahunnya dengan laju pertumbuhan penduduk 2,33 \%.Hal ini mengakibatkan terjadinya konversi penggunaan lahan di daerah tersebut.

Kota Ambon secara geografis teletak antara $127^{0} .53^{\prime} 47^{\prime \prime}$ BT - $128^{0} .11^{\prime} 19^{\prime}$ ' BT dan $3^{0} 29^{\prime} 18^{\prime \prime}$ ' dan mempunyai luas wilayah sekitar $359,45 \mathrm{~km}^{2}$. Secara umum daerah ini terbagi menjadi lima kecamatan yaitu bagian timur (meliputi Kecamatan Leitimur Selatan), bagian tengah (Kecamatan Sirimau atau ibukota dan kecamatan Nusaniwe), bagian barat (meliputi Kecamatan Teluk Ambon dan Kecamatan Baguala).

Salah satu wilayah di Kota Ambon yang mengalami perkembangan sangat pesat adalah Kecamatan Sirimau yang terletak di bagian Tengah Kota Ambon dengan kepadatan penduduk 1.658 per $\mathrm{km}^{2}$. Hal ini disebabkan oleh tingginya tingkat kelahiran per tahun yang mengakibatkan terjadinya pertumbuhan penduduk cukup pesat dan kebutuhan akan pemukiman pun meningkat. Oleh sebab itu, terjadilah pembangunan pemukiman hampir diseluruh wilayah yang mengakibatkan terjadinya perubahan penggunaan lahan dari tahun ke tahun.

Penerapan Sistem Informasi Geografis (SIG) pada saat ini berkembang pesat dan melebur ke dalam aspek penataan dan pembangunan lingkungan hidup, tidak terkecuali dalam pengolahan data perubahan penggunaan lahan. Sistem yang berbasis informasi geografis ini adalah seperangkat sistem terdiri dari perangkat keras dan lunak serta pengguna (user) yang bekerja bersama-sama dalam menganalisis data geografis dengan hasil data yang lebih akurat dibandingkan menggunakan sistem konvensional. Dengan menggunakan hasil interpretasi foto udara selanjutnya diolah dengan komputer yang dilengkapi perangkat lunak Sistem Informasi Geografi (SIG). Data yang besar dapat diolah lebih cepat efisien dan dapat ditayangkan kembali karena data tersimpan dalam bentuk digital.

Berdasarkan pertimbangan tersebut diatas maka perlu dilakukan penelitian mengenai perubahan penggunaan lahan di Kecamatan Sirimau Kota Ambon. Penelitian ini bertujuan untuk melihat kenyataan yang ada dilapangan dan hasil klasifikasi dari citra satelit. Hasil penelitian ini kemudian bisa digunakan sebagai landasan pertimbangan dalam melakukan pembangunan pemukiman di Kecamatan Sirimau Kota Ambon sekaligus bisa dijadikan data rujukan untuk membuat peraturan daerah dan tata ruang wilayah Kota Ambon.

Berdasarkan fokus penelitian diatas, maka tujuan yang ingin dicapai dalam penelitian ini adalah: (1) untuk mengetahui agihan perubahan penggunaan lahan di Kecamatan Sirimau Kota Ambon dilihat dari citra satelit tahun 2006 dan 2016, 
(2) untuk mengetahui luasan masingmasing perubahan penggunaan lahan Kecamatan Sirimau Kota Ambon dari tahun 2006 dan 2016, dan (3) untuk mengetahui faktor-faktor yang mempengaruhi terjadinya perubahan penggunaan lahan di Kecamatan Sirimau Kota Ambon.

\section{Penggunaan Lahan (land use)}

Penggunaan lahan (land use) diartikan sebagai setiap bentuk intervensi (campur tangan) manusia terhadap lahan dalam rangka memenuhi kebutuhan hidupnya baik material maupun spiritual. Penggunaan lahan dapat dikelompokkan ke dalam dua golongan besar yaitu penggunaan lahan pertanian. Penggunaan lahan pertanian dibedakan berdasarkan atas penyediaan air dan komoditi yang diusahakan dan di manfaatkan atau atas jenis tumbuhan atau tanaman yang terdapat diatas lahan tersebut. Berdasarkan hal ini dikenal macam penggunaan lahan seperti tegalan (pertanian lahan kering atau pertanian pada lahan tidak beririgasi), sawah, kebun kopi, kebun karet, padang rumput, hutan produksi, hutan lindung, padang alang-alang, dan sebagainya (Arsyad, 2010).

Perubahan tutupan lahan, di banyak bagian belahan dunia telah menjadi isu global, sebagai sebagai hasil kontribusi terdapat transformasi lengkap hadir dari jenis tutupan lahan. Bencana alam seperti kekeringan, banjir yang disebabkan oleh perubahan iklim, seperti di sarankan dalam banyak literatur bukanlah fenomena umum yang terjadi, intervensi manusia namun menyebabkan perubahan dramatis dalam masyarakat. FAO (1976) mengemukakan bahwa, seperti proses yang disebabkan manusia yang maju pada tingkat yang lebih cepat. Kekuatan yang paling ampuh mempengaruhi alam vegetasi muncul dari efek langsung pada populasi manusia berkembang (Grime, 1997 dalam Tahir et al, 2013).

\section{Perubahan Penggunaan Lahan}

Perubahan penggunaan lahan secara langsung menyebabkan terjadinya perubahan tutupan lahan. Pengertian tentang penggunaan lahan dan penutupan lahan penting untuk berbagai kegiatan perencanaan dan pengelolaan yang berhubungan dengan permukaan bumi. Penutupan lahan berkaitan dengan jenis kenampakan yang ada dipermukaaan bumi, sedangkan penggunaan lahan berkaitan dengan kegiatan manusia pada bidang lahan tertentu (Lillesand dkk, 1993). Penggunaan lahan (land use)juga diartikan sebagai setiap bentuk intervensi (campur tangan) manusia terhadap lahan dalam rangka memenuhi kebutuhan hidupnya baik material maupun spiritual, sedangkan perubahan tutupan lahan lebih kepada adanya perubahan vegetasi (Arsyad, 2006 dalam Nilda, 2014).

Selanjutnya Arsyad (2006) menyatakan bahwa, perubahan penggunaan lahan memiliki dampak potensial besar terhadap lingkungan bio-fisik dan sosial ekonomi. Secara umum penggunaan lahan digolongkan ke dalam dua golongan yaitu:

1. Penggunaan lahan pedesaan, secara umum dititikberatkan pada produksi pertanian, termasuk pengelolaan sumberdaya alam dan kehutanan.

2. Penggunaan lahan perkotaan secara umum dititikberatkan untuk tempat tinggal, pemusatan ekonomi, layanan jasa dan pemerintahan.

Kejadian perubahan penggunaan lahan akan mempengaruhi keseluruhan sistem ekologi termasuk hidrologi pada wilayah DAS tersebut. Pada skala besar dampak perubahan tersebut adalah terjadinya gangguan perilaku air sungai, pada musim hujan debit air akan meningkat tajam sementara pada musim kemarau debit air sangat rendah (Asdak, 2007). 
Faktor Terjadinya Perubahan Penggunaan Lahan

Menurut Darmawan (2002) salah satu faktor yang menyebabkan terjadinya perubahan penggunaan lahan adalah factor sosial ekonomi masyarakat yang berhubungan dengan kebutuhan hidup manusia utamanya masyarakat sekitar kawasan. Tingginya tingkat kepadatan penduduk di suatu wilayah mendorong penduduk untuk membuka lahan baru untuk digunakan sebagai permukiman ataupun lahan-lahan budidaya. Tingginya kepadatan penduduk akan meningkatkan tekanan terhadap hutan. Mata pencaharian penduduk di suatu wilayah berkaitan erat dengan kegiatan usaha yang dilakukan penduduk di wilayah tersebut.

Kementerian pekerjaan umum dan penyusunan program penanganan bencana alam bidang penataan ruang dalam Muta'ali, (2012) mengelompokkan bencana berdasarkan penyebabnya menjadi tiga jenis:

1. Bencana alam (natural disaster) bencana alam merupakan fenomena atau gejala alam yang disebabkan oleh keadaan geologi, biologis, seismis, hidrologis atau disebabkan oleh suatu proses dalam lingkungan alam mengancam kehidupan, struktur dan perekonomian masyarakat serta menimbulkan malapetaka.

2. Bencana akibat ulah manusia (manmade disaster) bencana karena ulah manusia merupakan peristiwa yang terjadi karena proses teknoogi, interaksi manusia terhadap lingkungannya serta interaksi antara manusia itu sendiri yang dapat menimbulkan dampak negatif terhadap kehidupan dan penghidupan masyarakat.

3. Bencana kombinasi: bencana ini dapat disebabkan oleh ulah manusia maupun oleh alam itu sendiri. Bencana ini dapat disebabkan oleh kedaan geologi, biologis, seismis, hidrologis atau disebabkan oleh suatu proses dalam lingkungan alam maupun teknologi, interaksi manusia terhadap lingkungannya serta interaksi antara manusia itu sendiri.

\section{SIG (Sistem Informasi Geografi)}

SIG merupakan suatu system yang mengorganisir perangkat keras (hardware), perangkat lunak (software), dan data serta dapat mendayagunakan sistem penyimpanan, pengolahan, maupun analisis data secara simultan, sehingga dapat diperoleh informasi yang berkaitan dengan aspek keruangan (Aronoff, 1989). Keterkaitan citra satelit dan system informasi geografi (SIG) dengan sumber daya air khususnya untuk pengelolaan dan pengembangan DAS antara lain meliputi: perbatasan daerah, pengukuran kedalaman air, studi tentang drainase, masalah erosi, pengendalian banjir, survey tanah, geografi, geologi, hidrologi, rencana pengairan, klasifikasi lahan, inventarisasi sumber daya lahan, kapasitas penampung air, air sungai dan pasang surut pengelaolaan DAS, dan lain-lain (Sutanto, 1994).

\section{Metode Penelitian}

Penelitian ini dilaksanakan di Kecamatan Sirimau Kota Ambon yang terletak antara $3^{0}-4^{0}$ Lintang Selatan dan $128^{0}-129^{0}$ Bujur Timur.

\section{Alat dan Bahan}

Alat dan bahan yang digunakan dalam penelitian ini adalah alat tulis, camera, GPS dan Peta.

\section{Sumber data Penelitian}

Bappeda Kota Ambon, BPS Kota Ambon, Peta Topografi lembar Ambon skala 1:25.000 dan citra satelit.

\section{Teknik Pengumpulan Data}

Pengumpulan data yang penulis gunakan adalah studi pustaka yaitu untuk mencari, mengumpulkan dan mempelajari literatur 
yang memuat topic-topik yang berkaitan dengan penelitian, menghubungi instansiinstansi terkait seperti BAPPEDA, BPS untuk menambah dokumentasi data serta mempersiapkan data peta Topografi lembar Ambon skala 1:25.000 dan citra satelit yang akan digunakan dalam penelitian.

\section{Teknik Pengolahan Data}

Setelah data-data yang dibutuhkan terkumpul maka langkah selanjutnya adalah melakukan pengolahan citra yang telah ada tahap pengolahan ini sebagai berikut: kegiatan pertama yang dilakukan adalah melakukan import data citra satelit menggunakan aplikasi SIG. aplikasi yang biasa digunakan adalah ArcGis versi 10.3, aplikasi ini memiliki banyak fasilitas import yang dapat digunakan untuk mengimport data raster dan veckor dalam berbagai format.

Selanjutnya koreksi radiometrik dan geometrik. Korekasi radiometrik bertujuan untuk memperbaiki nilai pixel agar sesuai dengan warna asli. Koreksi geoetrik ini dilakukan pada software ArcGis. Dalam melakukan koreksi geometrik terlebih dahulu dilakukan tipe proyeksi dan sistem koordinasi dan proyeksi yang sama perlu dilakukan untuk mempermudah proses pengintegrasian data-data selama penelitian.

Tahap selanjutnya pemotongan citra. Dilakukan dengan memotong wilayah yang menjadi lokasi penelitian. Klasifikasi terpantau/terbimbing hal ini digunakan untuk memisahkan/mengglongkan penutup suatu lahan diatas citra berdasarkan keseragaman atau kemiripan antara nilai piksel citra lokasi. Validasi data untuk mengetahui akurasi citra dalam mengelompokkan objek yang teridentifikasi sebagai jenis-jenis penutupan lahan yang sesuai fungsinya.

\section{Teknik Analisis Data}

Teknik analisis data dalam penelitian ini adalah analisis menggunakan SIG dan deskriptif, data yang diperoleh dari hasil analisis SIG disajikan dalam bentuk peta overlay yaitu peta penggunaan lahan tahun 2006 dan 2016. Peta ini kemudian di tumpang tindih, kemudian menghasilkan peta baru dan table perubahan penggunaan lahan kemudian dijelaskan secara deskriptif. Selanjutnya data yang diperoleh dianalisis kembali dengan teknik analisis spasial keruangan untuk memaparkan perubahan penggunaan lahan dan agihan penggunaan lahan yang terjadi di Kecamatan Sirimau Kota Ambon dalam kurun waktu 10 tahun dengan menggunakan Software ArcGis versi 10.3.

\section{Hasil dan Pembahasan}

\section{Analisis Perubahan Penggunaan Lahan}

Citra yang digunakan dalam penelitian ini adalah citra landsat 8 ETM tahun 2006 dan 2016. Interpretasi citra landsat 8 ETM dilakukan dengan melihat karakteristik dasar kenampakan masing-masing penggunaan lahan pada citra yang dibantu dengan unsur-unsur interpretasi. Penggunaan lahan di Kecamatan Sirimau Kota Ambon Tahun 2006 berupa hutan, kebun campuran, lahan kosong, pelabuhan, pemukiman, pertanian lahan kering, dan rawa. Hal itu tercermin dalam Tabel 1 berikut ini:

Tabel 1. Penggunaan Lahan Kecamatan Sirimau Tahun 2006

\begin{tabular}{llcc}
\hline No & $\begin{array}{c}\text { Penggunaan } \\
\text { Lahan 2006 }\end{array}$ & $\begin{array}{c}\text { Luas } \\
\text { (ha) }\end{array}$ & $\begin{array}{c}\text { Presentase } \\
\text { \% }\end{array}$ \\
\hline 1 & Hutan & 61.2 & 1.7 \\
\hline 2 & $\begin{array}{l}\text { Kebun } \\
\text { campuran }\end{array}$ & 2028.6 & 55.1 \\
\hline 3 & Lahan kosong & 60.3 & 1.6 \\
\hline 4 & Pelabuhan & 15.4 & 0.4 \\
\hline 5 & Permukiman & 966.9 & 26.3 \\
\hline 6 & $\begin{array}{l}\text { Pertanian } \\
\text { Lahan Kering }\end{array}$ & 91.8 & 2.5 \\
\hline
\end{tabular}




\begin{tabular}{lccc}
\hline 7 & Rawa & 454.4 & 12.4 \\
\hline & Luas Lahan & $\mathbf{3 6 7 8 . 6}$ & $\mathbf{1 0 0 . 0}$ \\
\hline
\end{tabular}

Sumber: Data Sekunder Hasil Pengolahan

Berdasarkan Tabel 1 diatas menunjukkan bahwa penggunaan lahan terluas di Kecamatan Sirimau berupa penggunaan lahan kebun campuran memiliki luas 2028.6 Ha dengan presentase 55.1\% dari keseluruhan luas wilayah Kecamatan Sirimau. Kedua terbesar penggunaan lahan permukiman seluas $966.9 \mathrm{Ha}$ dengan persentase $26,3 \%$ dari keseluruhan luas wilayah Kecamatan Sirimau. Ketiga terbesar rawa dengan luas $454.4 \mathrm{Ha}$ dengan presentase $12.4 \%$, pertanian lahan kering 91,8 Ha dengan presentase 2,5\%, hutan dengan luas $61.2 \mathrm{Ha}$ dengan presentase $1,7 \%$, penggunaan lahan kosong seluas $60.3 \mathrm{Ha}$ dengan presentase $1,6 \%$, dan pelabuhan dengan luas $15.4 \mathrm{Ha}$ dengan persentase $0,4 \%$.

Penggunaan lahan di Kecamatan Sirimau tahun 2006 sama dengan penggunaan lahan pada tahun 2016 hanya luasnya yang berubah. Penggunaan lahan di Kecamatan Sirimau tahun 2016 dapat dilihat pada Tabel 2.

Tabel 2.Penggunaan Lahan Kecamatan Sirimau Tahun 2016

\begin{tabular}{|c|c|c|c|}
\hline No & $\begin{array}{l}\text { Penggunaan } \\
\text { Lahan } 2016 \\
\end{array}$ & $\begin{array}{c}\text { Luas } \\
\text { (ha) }\end{array}$ & $\begin{array}{c}\text { Presentase } \\
\%\end{array}$ \\
\hline 1 & Hutan & 49.8 & 1.4 \\
\hline 2 & $\begin{array}{l}\text { Kebun } \\
\text { Campuran }\end{array}$ & 1873.5 & 50.9 \\
\hline 3 & $\begin{array}{l}\text { Lahan } \\
\text { Kosong }\end{array}$ & 169.8 & 4.6 \\
\hline 4 & Pelabuhan & 15.4 & 0.4 \\
\hline 5 & Pemukiman & 1036.1 & 28.2 \\
\hline 6 & $\begin{array}{l}\text { Pertanian } \\
\text { Lahan Kering }\end{array}$ & 160.7 & 4.4 \\
\hline 7 & Rawa & 373.2 & 10.1 \\
\hline & $\begin{array}{l}\text { enggunaan } \\
\text { Lahan }\end{array}$ & 3678.6 & 100.0 \\
\hline
\end{tabular}

Data Sekunder Hasil Pengolahan
Tabel 2 di atas menunjukkan bahwa penggunaan lahan di Kecamatan Sirimau tahun 2016 sama dengan penggunaan lahan pada tahun 2006 hanya luas dan persentasenya yang berbeda. Penggunaan lahan berupa permukiman pada tahun 2006 adalah 966,9 Ha pada tahun 2016 menjadi seluas 1036,1 Ha, artinya terjadi pertambahan permukiman selama 10 tahun terakhir sebesar 69,5 Ha. Sedangkan perubahan penggunaan lahan pertanian lahan kering tahun 2006 adalah 91,8 Ha pada tahun 2016 menjadi 160,7 Ha artinya terjadi peningkatan sebanyak $68,9 \mathrm{Ha}$, dan lahan kosong pada tahun 2006 adalah 60,3 Ha pada tahun 2016 bertambah menjadi 169,8 Ha, sedangkan untuk kebun campuran pada tahun 2006 menjadi 2028,6 Ha pada tahun 2016 berkurang menjadi $1873,5 \mathrm{Ha}$.

Untuk melihat lebih jelas bagaimana penggunaan lahan di Kecamatan Sirimau Kota Ambon tahun 2006 dan 2016 setelah di tumpang tindih atau overlay peta tersebut dapat dilihat pada Gambar 1.

Berdasarkan hasil interpretasi, penggunaan lahan terbanyak berturut-turut di Kecamatan Sirimau Kota Ambon tahun 2016 adalah permukiman, pertanian lahan kering, kebun campur, lahan kosong, hutan, pelabuhan dan rawa. Berdasarkan Tabel 3, perubahan penggunaan lahan berupa kebun campur di Kecamatan Sirimau Kota Ambon 2028,6 Ha dengan presentase sebesar $55,1 \%$ berkurang menjadi 1873,5 Ha dengan persentase sebesar 50,9 \%. Lahan kebun campur ini berubah menjadi permukiman sebesar 155,1 Ha, lahan kosong 160,7 Ha, pertanian lahan kering 91,8 $\mathrm{Ha}$, rawa 20,5 Ha dan hutan 13,2 Ha.

\section{Faktor Perubahan Penggunaan Lahan}

Faktor yang mempengaruhi yang mempengaruhi perubahan penggunaan lahan adalah petambahan penduduk yang sangat signifikan, berdasarkan data BPS Kota Ambon jumlah penduduk Kecamatan 
Sirimau tahun 2016 adalah 167.197 jiwa $(42,28 \%)$ dengan kepadatan 1.925 jiwa $/ \mathrm{km}^{2}$. Artinya setiap 1 kilometer wilayah kecamatan Sirimau di huni oleh 1.925 jiwa dengan jumlah penduduk yang relative banyak dan luas wilayah dengan pertumbuhan penduduk pesat membuat kebutuhan penduduk di Kecamatan Sirimau pun ikut bertambah, terutama kebutuhan akan permukiman.

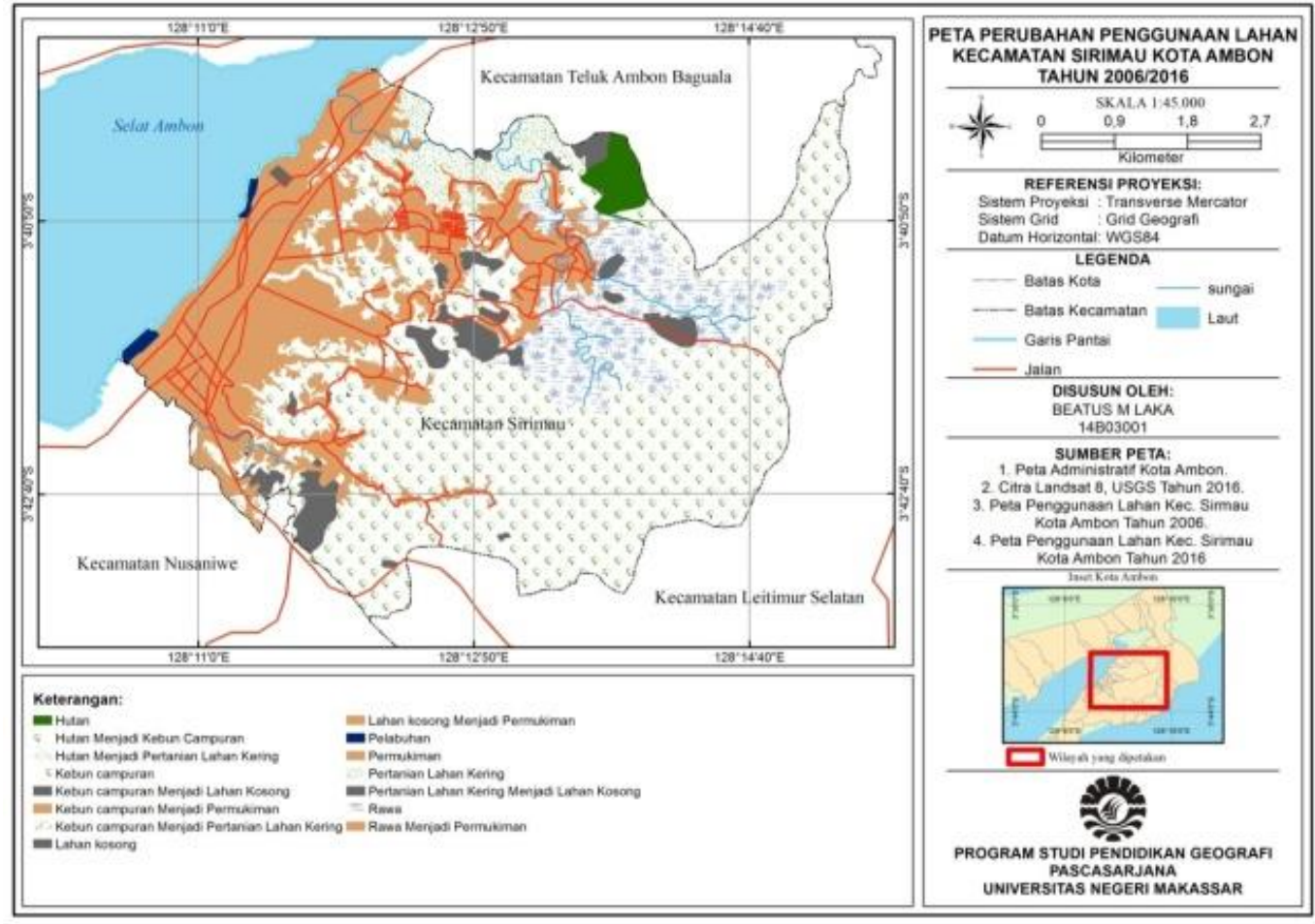

Gambar 1. Peta perubahan penggunaan lahan tahun 2006/2016

Tabel 3. Matriks perubahan penggunaan lahan (Ha) tahun 2006 dan 2016

\begin{tabular}{|c|c|c|c|c|c|c|c|c|c|}
\hline No & $\begin{array}{l}\text { Perubahan } \\
\text { Penggunaan } \\
\text { lahan tahun } \\
\text { 2006-2016 }\end{array}$ & 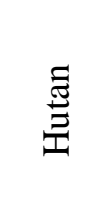 & 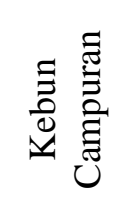 & 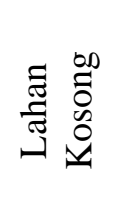 & 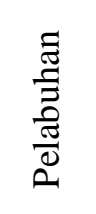 & 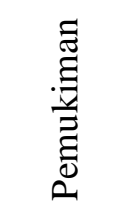 & 䓌 & 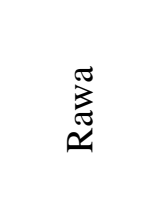 & $\begin{array}{c}\text { Jumlah } \\
\text { tahun } \\
2006\end{array}$ \\
\hline 1 & Hutan & 49.ha & $11 \mathrm{ha}$ & & & & 0.4 ha & & $61.2 \mathrm{ha}$ \\
\hline 2 & $\begin{array}{c}\text { Kebun } \\
\text { campuran }\end{array}$ & & $\begin{array}{c}1862.5 \\
\text { ha }\end{array}$ & $\begin{array}{c}66.6 \\
\text { ha }\end{array}$ & & $\begin{array}{c}43.8 \\
\text { ha }\end{array}$ & $\begin{array}{c}61.9 \\
\text { ha }\end{array}$ & & $\begin{array}{c}20128.6 \\
\text { ha }\end{array}$ \\
\hline 3 & $\begin{array}{c}\text { Lahan } \\
\text { Kosong }\end{array}$ & & & $\begin{array}{c}99.6 \\
\text { ha }\end{array}$ & & 7.7 ha & & & 60.3 ha \\
\hline 4 & Pelabuhan & & & & $\begin{array}{c}15.4 \\
\text { ha }\end{array}$ & & & & 15.4 ha \\
\hline 5 & Pemukiman & & & & & $\begin{array}{c}972.5 \\
\text { ha }\end{array}$ & & & 966.9 ha \\
\hline 6 & $\begin{array}{c}\text { Pertanian } \\
\text { Lahan } \\
\text { Kering } \\
\end{array}$ & & & $\begin{array}{l}3.6 \\
\text { ha }\end{array}$ & & & $\begin{array}{c}98.4 \\
\text { ha }\end{array}$ & & 91.8 ha \\
\hline 7 & Rawa & & & & & $\begin{array}{c}12.2 \\
\text { ha }\end{array}$ & & 373.2 ha & 454.4 ha \\
\hline & $\begin{array}{c}\text { Jumlah } \\
\text { tahun } 2016\end{array}$ & $\begin{array}{c}49.8 \\
\text { ha }\end{array}$ & $\begin{array}{c}1873.5 \\
\text { ha }\end{array}$ & $\begin{array}{c}169.8 \\
\text { ha }\end{array}$ & $\begin{array}{c}14.5 \\
\text { ha }\end{array}$ & $\begin{array}{c}1036.2 \\
\text { ha }\end{array}$ & $\begin{array}{c}160.7 \\
\text { ha }\end{array}$ & 373.2 ha & 3678.6 ha \\
\hline
\end{tabular}


Berdasarkan hasil interpretasi penggunaan lahan di Kecamatan Sirimau Kota Ambon terbagi atasenam yaitu: permukiman, kebun campuran, lahan kosong, pertanian lahan kering, rawa dan hutan. Penggunaan lahan (land use) juga diartikan sebagai setiap bentuk intervensi (campur tangan) manusia terhadap lahan dalam rangka memenuhi kebutuhan hidupnya baik material maupun spiritual, sedangkan perubahan tutupan lahan lebih kepada adanya perubahan vegetasi (Arsyad, 2006 dalam Nilda, 2014). Perubahan Penggunaan lahan di Kecamatan Sirimau Kota Ambon 10 tahun terakhir mengalami perubahan yang signifikan diakibatkan oleh pertambahan penduduk sehingga terjadinya perubahan penggunaan lahan akibat campur tangan manusia untuk memenuhi kebutuhan hidupnya. Hal ini disebabkan karena masyarakat yang bermukim diwilayah Kecamatan Sirimau ini menggunakan lahan untuk bercocok tanam dan permukiman.

Adapun perubahan penggunaan lahan di bagian timur Kecamatan Sirimau di dominasi oleh perubahan kebun campuran, lahan kosong, dan rawa menjadi lahan permukiman. Perubahan yang paling jelas terjadi di bagian barat dan timur Kecamatan Sirimau karena terpusat pada satu titik, tidak tersebar di seluruh wilayah tersebut.

\section{Kesimpulan}

1. Perubahan luasan penggunaan lahan Kecamatan Sirimau Kota Ambon 10 tahun terakhir adalah penggunaan lahan untuk permukiman yang bertambah menjadi 1036,1 Ha dari tahun sebelumnya sebesar 966,9 Ha.

2. Agihan perubahan penggunaan lahan mengarah ke selatan dan timur. Perubahannya berupa perubahan lahan kosong, lahan pertanian kering, kebun campuran dan hutan berubah menjadi lahan permukiman.
3. Faktor yang mempengaruhi perubahan penggunaan lahan adalah lajunya tingkat pertumbuhan penduduk yaitu sebesar $5,54 \%$ dengan kepadatan penduduk kurang lebih $1.925 \mathrm{jiwa} / \mathrm{km}^{2}$.

\section{Daftar Pustaka}

Aronoff, S. (1989). Geographic Information System A Management Prespective. Ottawa - Canada: WDL Publication.

Arsyad, S. (2006). Konservasi Tanah dan Air. Bogor: IPB Press.

Arsyad, S. (2010). Konservasi Tanah dan Air. Bogor: IPB Press.

Asdak, C. (2007). Hidrologi dan Pengelolaan daerah Aliran Sungai. Yogyakarta: Gadjah Mada University Press.

Darmawan, A. (2002). Perubahan Penutupan Lahan di Cagar Alam Rawa Danau Bogor. Bogor: Jurusan Konservasi Sumber Daya Hutan, Fakultas Kehutanan, IPB.

FAO. (1976, No. 22). A Framework for Land Evaluation. FAO Soils Bulletin No. 32/I/ILRI.

Ismail. (1999). Alih Fungsi Lahan di Kawasan Industri Makassar. Makassar: Program Studi Geografi, UNM.

Muiz, A. (2009). Analisis Perubahan Penggunaan Lahan di Kabupaten Sukabumi. Bogor: Sekolah Pascasarjana IPB.

Muta'ali. (2012). Daya Dukung Lingkungan untuk Perencanaan Pengembangan Wilayah. Yogyakarta: Badan Penerbit Fakultas Geografi UGM.

Nilda. (2014). Analisis Perubahan Penggunaan Lahan dan Dampaknya Terhadap Hasil Air di DAS Cisadane Hulu. Bali: Universitas Udayana.

Suhendy, C. (2009). Kajian Spasial Kebutuhan Hutan Kota Berbasis Hidrologi di Kota Ambon. Ambon: Universitas Pattimura. 
Sutanto. (1994). Penginderaan Jauh. Yogyakarta: UGM Press.

Tahir. (2013). Evaluation of Land Use/Land Cover Changes in Mekelle City, Ethiopia Using Remote Sensing and GIS
Computational Ecology and Software. IAEES, 9-16.

TM. Lillesand, d. K. (1993). Penginderaan Jauh dan Interpretasi Citra. Yogyakarta: UGM Press. 